\title{
Rapid Spectrophotometric Determination of Phenoxazine
}

\author{
Karim. D. Khalaf* \\ Date of acceptance 13/5/2009
}

\begin{abstract}
:
A rapid high sensitive and inexpensive economic method has been developed for the Determination of phenoxazine by using molecular spectrophotometry. The method is based on the oxidation of phenoxazine by potassium (meta)periodate in acidic medium.

The oxidation conditions were selected to enhance the sensitivity and the stability of the pink colored species which shows an absorption maximum at $530 \mathrm{~nm}$. The Beer's law was obeyed for phenoxazine concentration range from 1 to $6 \mu \mathrm{g} \mathrm{mL}^{-1}$ with 0.003 $\mu \mathrm{g} \mathrm{mL} \mathrm{L}^{-1}$ detection limit and provided variation coefficients between 0.4 to $1.7 \%$. This method was successfully applied for the determination of phenoxazine in aqueous samples
\end{abstract}

Key words: phenoxazine, spectrophotometry, potassium metaperiodate.

\section{Introduction:}

Phenoxazine, firstly prepared in 1930 [1] and has found an extensive application, as the parent substance of a number of dyes and polymer derivates [2]. The physical properties make phenoxazine based compounds suitable for application in several industrial fields, including electro catalysis [3]. The hydrophobic phenoxazine ring promotes molecular aggregates in aqueous solution and such aggregates are important for several photo conversion applications such as photography [4].

Phenoxazine is a part of the chemical structure of antinomycine D, which is known to exert intensive anticancer activity on malignant tumors in children [5], and is a potent and low toxic chemosensitizer [6].

In recent years, phenoxazine derivatives have been widely used as chromogenic compounds in host-guest artificial photonic antenna system [7].

On the other hand phenoxazine has been used as analytical reagent for the determination of chlorine and nitrite in waters $[8,9]$. Also, it was found to have potential applications for an ozone visual monitor, a reaction product with exceptional stability was formed[10].

On surveying the literature, it was not found any method for the spectrophotometric determination of phenoxazine and hence, the purpose of this study has been to develop a simple method based on the oxidation of phenoxazine by potassium (meta)periodate in acidic medium to produce a colored species showing an absorption maximum at $530 \mathrm{~nm}$.

\section{Materials and methods : Apparatus}

All the absorbance measurements were carried out by using a HewlettPackard (Waldbronn, Germany) model 8452, diode-array spectrophotometer, equipped with 89530A MS-DOS-UVvisible software with a response time of 0.1 second.

\section{Reagents and solutions}

All reagents used were of the highest purity and most solutions were

\footnotetext{
*Department of Chemistry, College of Sciences for Women, University of Baghdad.
} 
prepared in ultra pure water with a resistivity of $18.2 \mathrm{M} \Omega \mathrm{cm}$, obtained from a Millipore Milli-Q system (Bedford, MA). Phenoxazine of $97.0 \%$ purity was obtained from Fluka (Buchs, Switzerland) and a stock standard solution was prepared daily by dissolving $25 \mathrm{mg}$ phenoxazine in $100 \mathrm{~mL}$ absolute ethanol.

Hydrochloric acid of $37 \%$ was obtained from Scharlau (Barcelona, Spain). Potassium (meta)periodate of 99.8\% purity was obtained from Fluka and a stock solution was prepared by dissolving $0.1( \pm 0.0001) \mathrm{g}$ in $250 \mathrm{~mL}$ ultra pure water in order to obtain $0.00174 \mathrm{~mol} \mathrm{~L}^{-1} \mathrm{KIO}_{4}$. The $10^{-4} \mathrm{~mol} \mathrm{~L}$

${ }^{1} \mathrm{KIO}_{4}$ working solution was prepared by dilution with ultrapure water. Both solutions were stable for long time at laboratory temperature.

\section{General procedure}

$10 \mathrm{~mL}$ of sample were transferred to a $25 \mathrm{~mL}$ volumetric flask and $10 \mathrm{~mL}$ of concentrated $\mathrm{HCl}$ were added. The mixture was shaken and $1 \mathrm{~mL} 10^{-4} \mathrm{~mol}$ $\mathrm{L}^{-1} \mathrm{KIO} 4$ was added and the volume was made up to $25 \mathrm{~mL}$ with ultra pure water. Absorbance measurements were carried out at $530 \mathrm{~nm}$ for the pink color by using a $1.0 \mathrm{~cm}$ quartz cell against reagent blank which was prepared in the same way but without phenoxazine.

\section{Result and Discussion}

\section{$U V$-Spectrum of phenoxazine}

Figure 1, shows the UV-spectrum of phenoxazine in water which presents three absorption maxima at 214, 236 and $312 \mathrm{~nm}$. The absorbance maximum at $312 \mathrm{~nm}$ was selected in order to obtain the best selectivity.

This was done by carrying out a calibration graph through the preparation of a series of standard solutions of $0,0.5,2,4$, and $6 \mu \mathrm{g} \mathrm{ml}^{-1}$ of phenoxazine in volumetric flasks of
$10 \mathrm{ml}$ diluting to the mark with ultra pure water.

Table 1 demonstrates the optical characteristic of the determination of phenoxazine in the UV-region.

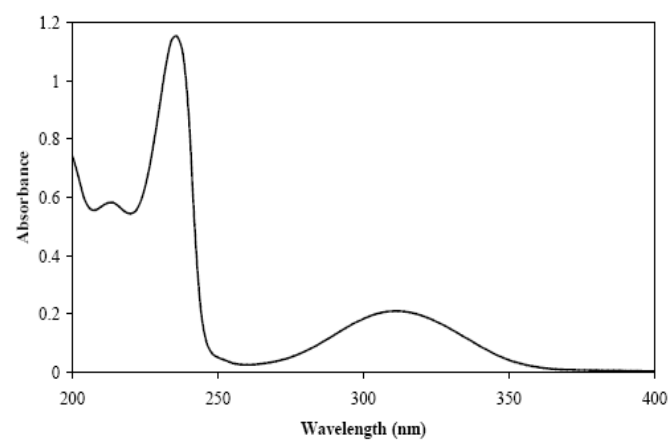

Figure 1: UV- absorption spectrum of $5 \mu \mathrm{g} \mathrm{mL}{ }^{-1}$ of phenoxazine in $12 \%$ ethanol.

Table 1. Spectral data for phenoxazine in UV - region

\begin{tabular}{|l|l|}
\hline \multicolumn{1}{|c|}{ Parameter } & UV-region \\
\hline Color & Colorless \\
\hline$\lambda$ max $(\mathrm{nm})$ & 312 \\
\hline Beer's law $\left(\mu \mathrm{g} \mathrm{mL}^{-1}\right)$ & $0.5-8$ \\
\hline Molar absorptivity $\left(\mathrm{L} \mathrm{mol}^{-1} \mathrm{~cm}^{-1}\right)$ & 8244 \\
\hline Limit of detection $\left(\mu \mathrm{g} \mathrm{m}^{-1}\right)$ & 0.016 \\
\hline Regression equation: & \\
\hline Slope $\left(\mathrm{mL} \mu \mathrm{g}^{-1} \mathrm{~cm}^{-1}\right)$ & 0.045 \\
\hline Intercept(a.u.) & 0.0069 \\
\hline Correlation coefficient $\AA$ & 0.9993 \\
\hline Variation coefficient $(\%)(\mathrm{n}=5)$ & $0.3-1.7$ \\
\hline
\end{tabular}

\section{Oxidation of phenoxazine}

Phenoxazine undergoes oxidation readily in a series of one electron steps to Yield radicals and ions and it has been described the oxidation of phenoxazine with Concentrated sulphuric acid [11] dimethylsulfoxide (DMSO)-acetic anhydride [12], Iodine in DMSO and aluminum trichloride in nitro methane [13], electrochemical Oxidation [14], flash photolysis [15] and cerium (IV), bromine and iron [16] xidation.

In the presence of hydrochloric acid, phenoxazine is oxidized by the dissolved $\mathrm{O}_{2}$. Different concentrations of $\mathrm{HCl}$ from $1 \mathrm{~mol} \mathrm{~L}^{-1}$ to $8 \mathrm{~mol} \mathrm{~L}^{-1}$ 
were assayed and it was found that 5 mol L ${ }^{-1} \mathrm{HCl}$ was the best one.

Figure 2 shows the UV-visible absorption spectra of the oxidation products Which indicate that phenoxazine is readily oxidized and yields four main absorption Bands at 210, 236, 310 and $530 \mathrm{~nm}$. The latter band being the most selective but less Sensitive than the other ones.

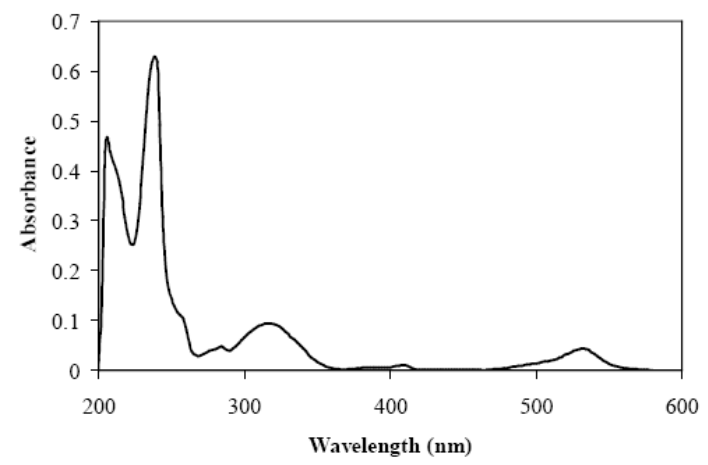

Figure 2: Study of the effect of dissolved $\mathrm{O}_{2}$ on the UV-visible spectrum of $5 \mu \mathrm{g} \mathrm{mL}^{-1}$ Phenoxazine in acidic medium of $5 \mathrm{~mol} \mathrm{~L}^{-1} \mathrm{HCl}$.

Phenoxazine can be quantitatively oxidized by potassium (meta) periodate in $5 \mathrm{~mol} \mathrm{~L}^{-1}$ in hydrochloric acid medium. The effect of potassium (meta) periodate concentration was studied in the range from $10^{-6}$ to $10^{-3} \mathrm{~mol} \mathrm{~L}^{-1}$. Figure -3 (A) shows that the best results were found at $10^{-5} \mathrm{~mol} \mathrm{~L}^{-1} \mathrm{KIO}_{4}$ and higher concentration of $\mathrm{KIO}_{4}$ causes the destruction of the colored species. Figure-3- (B), shows the absorption spectrum of phenoxazine after oxidation by potassium (meta) periodate, and in this spectrum, it can be seen that the $530 \mathrm{~nm}$ absorption band has been dramatically increased as compared with spectra found in the absence of $\mathrm{KIO}_{4}$.

The color development was very rapid and remained constant and stable for more than twelve hours even at temperatures till $100^{\circ} \mathrm{C}$.
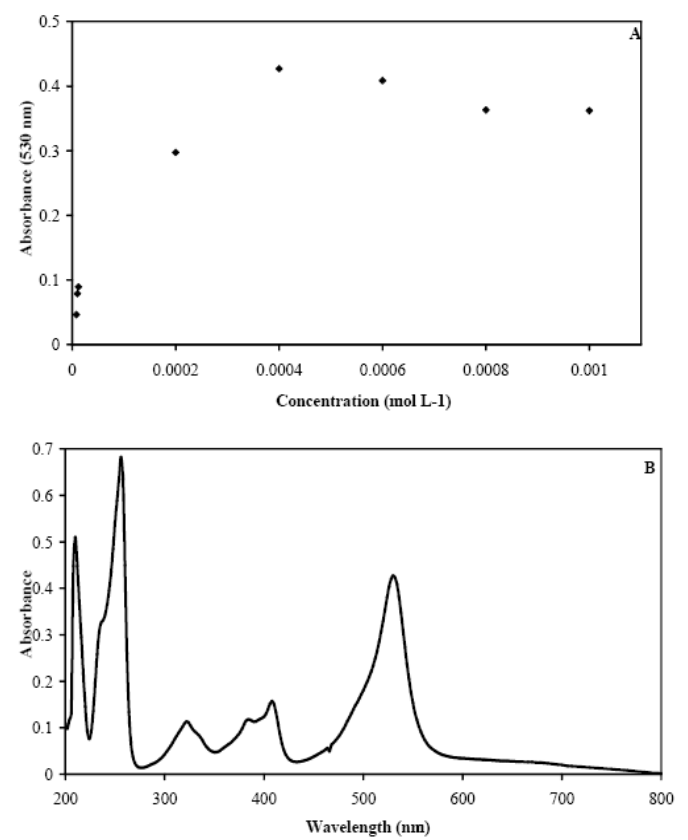

Figure3: (A) Effect of the potassium metaperiodate concentration on the absorption at $530 \mathrm{~nm}$ of a phenoxazine solution of $5 \mu \mathrm{g} \mathrm{mL} \mathrm{L}^{-1}$. (B) UV-visible spectrum of the Oxidation product of $5 \mu \mathrm{g} \mathrm{mL} \mathrm{m}^{-1}$ phenoxazine by using $10^{-5} \mathrm{~mol} \mathrm{~L}^{-1}$ $\mathrm{KIO}_{4}$.

The proposed reaction mechanism may be similar to that proposed by Hanson and Norman [17] which is showed in the following scheme: 


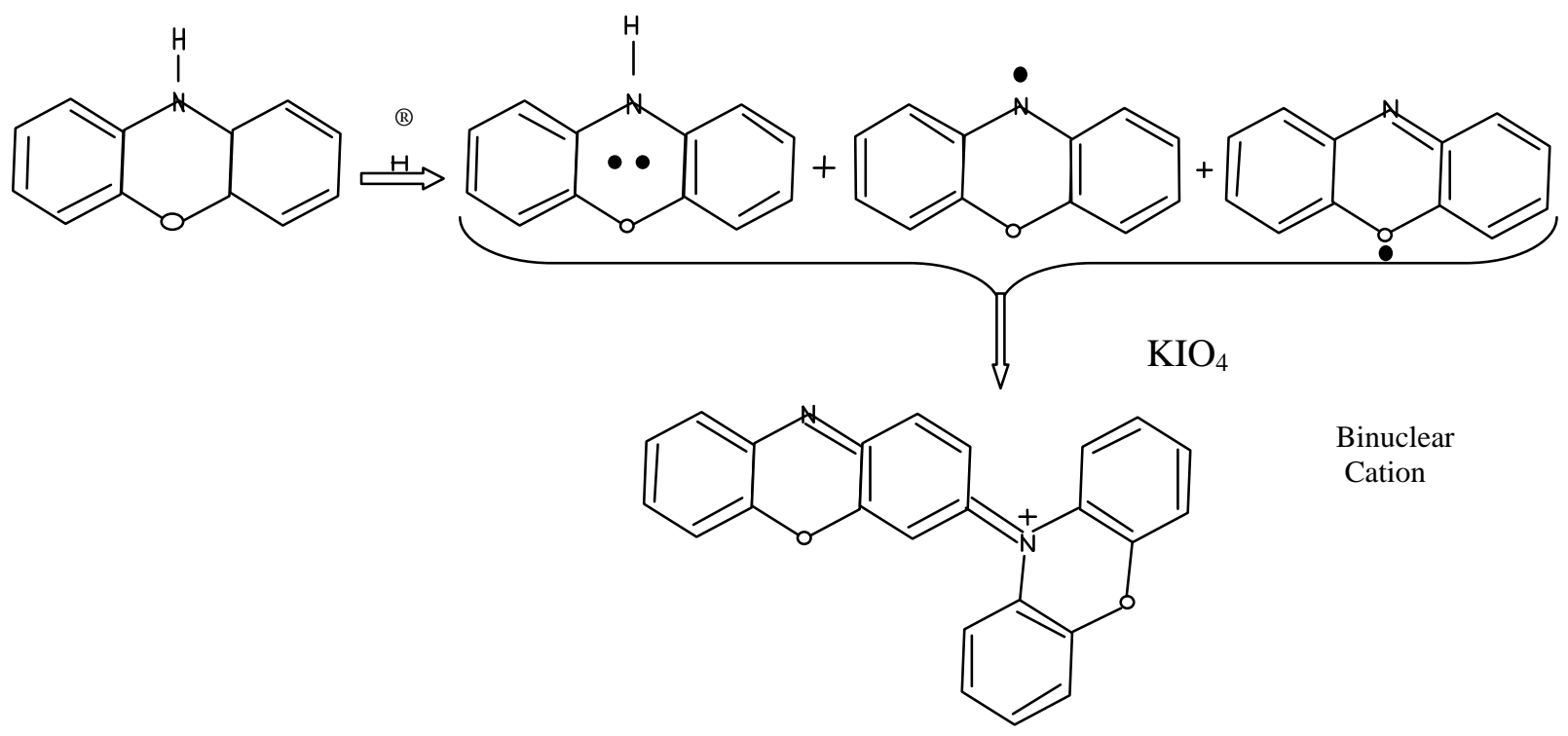

\section{Analytical figures of merit}

The optical characteristics for the determination of phenoxazine after oxidation by potassium (meta) periodate were established from a series of standard solutions on the concentration range from $\left(1-6 \mu \mathrm{g} \mathrm{m}{ }^{-}\right.$ $\left.{ }^{1}\right)$. Table-1 the analytical figures and merit of the proposed method.

Table2. Spectral data for phenoxazine in UV-visible region

\begin{tabular}{|c|c|c|}
\hline Parameter & Uv-region & $\begin{array}{l}\text { Visible } \\
\text { region }\end{array}$ \\
\hline Color & Colourless & Pink \\
\hline$\lambda \max (\mathrm{nm})$ & 312 & 530 \\
\hline Beer's law $\left(\mu \mathrm{g} \mathrm{mL}^{-1}\right)$ & $0.5-8$ & $1-6$ \\
\hline $\begin{array}{l}\text { Molar absorptivity }\left(\mathrm{L} \quad \mathrm{mol}^{-1}\right. \\
\left.\mathrm{cm}^{-1}\right)\end{array}$ & 8244 & 16778 \\
\hline Limit of detection $\left(\mu \mathrm{g} \mathrm{mL}^{-1}\right)$ & 0.016 & 0.003 \\
\hline \multicolumn{3}{|l|}{ Regression equation: } \\
\hline Slope $\left(\mathrm{mL} \mu \mathrm{g}^{-1} \mathrm{~cm}^{-1}\right)$ & 0.045 & 0.091 \\
\hline Intercept(a.u.) & 0.0069 & 0.0097 \\
\hline Correlation coefficient ${ }^{\circledR}$ & 0.9993 & 0.9996 \\
\hline Variation coefficient $(\%)(\mathrm{n}=5)$ & $0.3-1.7$ & $0.4-1.7$ \\
\hline
\end{tabular}

\section{Analysis of phenoxazine in water}

The proposed method was applied to the determination of phenoxazine in spiked tap water.

Table 2, shows the obtained results of added quantities of phenoxazine and the standard deviation which provides quantitative recoveries in the range between 95.3 to $98.7 \%$ in spite of the presence of interfering ions which are normally present in tap water.
Table3. Determination of phenoxazine in spiked tap water

\begin{tabular}{|c|c|c|}
\hline $\begin{array}{c}\text { Phenoxazine } \\
\text { added } \\
\left(\boldsymbol{\mu} \mathbf{~ m L}^{-1}\right)\end{array}$ & $\begin{array}{c}\text { Phenoxazine } \\
\text { found } \\
\left(\boldsymbol{\mu} \mathbf{g ~ m L}^{-\mathbf{1}}\right)\end{array}$ & $\begin{array}{c}\text { Recovery } \\
(\boldsymbol{\%})\end{array}$ \\
\hline 1.5 & $1.430 \pm 0.006$ & $95.3 \pm$ \\
& $2.43 \pm 0.08$ & 0.4 \\
\hline 2.5 & $3.33 \pm 0.08$ & $95 \pm 3$ \\
\hline 3.5 & $4.44 \pm 0.01$ & $98.7 \pm 0.2$ \\
\hline 4.5 & \multicolumn{3}{|l}{} \\
\hline
\end{tabular}

\section{References:}

1. The Merck Index, 14th Ed. Merck \& Co. Inc., White House Station, $\mathrm{Nj}$, USA, 2006.7253.

2. Anfenogenof A.V.; Khlebnikov F.A.; Filimonov.D V., . Ogorodnikof D.V., 1989. Chemistry of Heterocyclic compounds; New York, Vol.24 (12) 1384.

3. Gorton.L., 1986 . J. Chem. Soc. Faraday Trans. 821245.

4. Steinhurst .A.D, J.C. Owrut Sky, 2001 . J. Phys. Chem. B, 1053062.

5. Ishida R, Yamanaka S., Kawai H., Ho .H., Lwai ,Nishizawa M., Hamatake M And Tomoda A, 1996 . Anti-cancer Drugs 7591.

6. Thimmaiah $\mathrm{N}$ K., Harton $\mathrm{K}$ J., Qian D X., Beck T W., Houghton A J. and Houghton .G. P. , 1990 . Cancer Common, 2249. 
7. Calzaferri G., Pauchared M, Maas $\mathrm{H}$, Huber S, Khatyr A, and Schaafsma T, T. 2002 .Mater. Chem., 12136.

8. Al-Okab A. R, and Syed A.A, 2007. Talanta, 72(4) 1239.

9. Al-Okab A.R, and Syed A.A, 2008. J. Molecular Liquid 137 110.

10. Lambert L .J, Liao .L .Y ,and Paukstells V J., 1987 . Environ. Sci. Technol. 21503.

11. Sullivan D. P, and Btton R. J, 1969 . J. Magnetic Resonance 1 356.
12. Sutcliffe H. L, and Walkly J, 1958 . Nature 178999.

13. Chiu F .M, Gilbert C. B, and Hanson P , 1970, J. Chem. Soc (B) 1700.

14. Billon P. J, 1962 . Ann. Chim. (France) 7183.

15. Gegiu D, Huber R. J, and Wfiss K, 1970 . J. Amer. Chem. Soc. 92 5058.

16. Kemp J .T , Moore P, and Quick R G., 1980 . J.C.S Perkin 291.

17. Hanson P, and Norman C .O.R., 1973 . J.C.S Perkin 26.

\section{التقرير الطيفي السريع لمركب الفينوكسازين}

كرييم لديمه خلف*

* جامعه بغداد - كليه العلوم للبنات - قسم الكيمياء

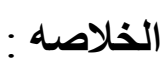

يتضمن البحث تطوير طريقه جديده للثقدير الكمي لمركب الفينو كسازين في محاليله المائيه باستخدام مطيافيه

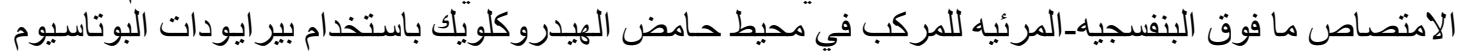

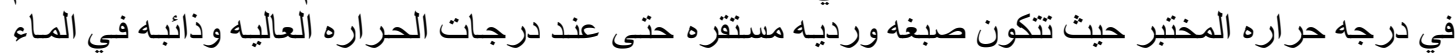

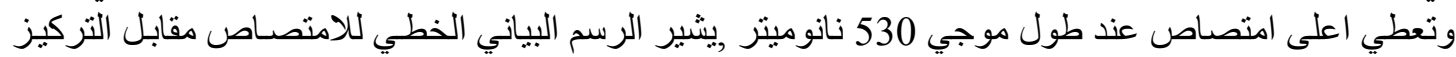

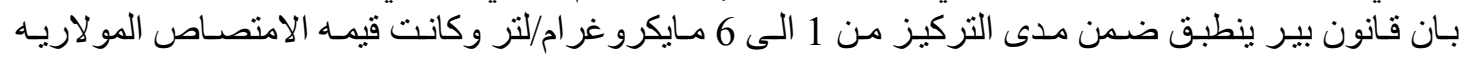

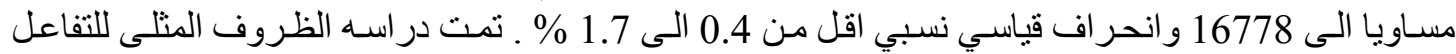
وطبقت الطريقه على تحديد تركيز المركب في محاليله المائيه. 